\title{
Examining the Relation between Physical Characteristics of 10-12 Year-Old Male Tennis Players and Forehand and Backhand Stroke Speeds
}

\author{
Büşra Taş \\ Faculty of Sports Sciences, Süleyman Demirel University, Isparta, Turkey \\ Tel: 90-546-927-0559Ｅ-mail: busra96tas@gmail.com \\ Yunus Emre Bağış (Corresponding author) \\ Faculty of Sports Sciences, Süleyman Demirel University, Isparta, Turkey \\ Tel: 90-506-824-2322 E-mail: yunusbagis@sdu.edu.tr
}

Received: April 8, 2020 Accepted: May 17, 2020 Published: May 27, 2020

doi:10.5296/jei.v6i1.16810 URL: https://doi.org/10.5296/jei.v6i1.16810

\begin{abstract}
In the present study, the purpose was to examine the effects of some physical characteristics on the stroke speed in forehand and backhand techniques in tennis. The Study Group consisted of 10-12-year-old tennis players of Isparta Süleyman Demirel University Tennis Courts (mean age 10.15 \pm .37 (years), mean height $1.46 \pm .06$ (m) mean body weight $38.77 \pm 6.67(\mathrm{~kg})$, mean sports age $4.76 \pm 1.16$ (years)). Forehand and backhand strokes were performed in a closed tennis court to control the effect of the weather in measuring ball speed. The athletes warmed up until they reached maximal forehand and backhand speed levels. Three minutes after the athletes warmed up, the tests were started. They were asked to perform forehand and backhand strokes at 8 maximal speed. Sports Radar, Power Madd was used to measure the ball speed. The measurements of the radar used to measure the speed of the ball were taken at the time of the strokes and immediately after the strokes. The strokes were made in line with the rules of tennis, towards the court, and when the ball stroke the net or when it went outside the baseline (out), these strokes were not recorded. The feedbacks of the strokes were reported to the athletes to spend maximal effort. All strokes were directed towards the parallel point of the court. The coach behind the file sent the balls to the athletes for strokes, and all strokes were evaluated by two tennis coaches. The "Descriptive Statistics" and "Correlation Analysis" in the statistical package program to analyze the data.
\end{abstract}


Significance level was taken as " $p<0.05$ ". As a result, sports scientists and coaches must pay attention to technical development levels of athletes as well as their physical characteristics in the preparation of a training program for 10-12 year old male tennis players. It can be considered that strength development can be achieved with an accurate technique; and depending on this, the speed of the ball will increase. Since physical development is mostly at directly proportional to age, it is considered that ball speed will be affected as the age increases.

Keywords: Tennis, Forehand, Backhand, Stroke speed

\section{Introduction}

Since tennis activates many muscle groups, it is important that physical fitness level is high. Fast arm movements, jumps, moves and force are needed (Pektas, 2016). It was especially determined that the development of force is an element affecting the skill of tennis and the performance of the competition. In order for tennis players to perform a higher level in tennis, they must firstly develop technical and tactical characteristics, and then, they must consider psychological and physiological factors as well as structural factors. On the other hand, body measurements and ratios, physics and body composition are important factors affecting physical performance (Sogut et al., 2004).

Researches showed that elite tennis players have a higher body mean than normal players. Besides, their upper and lower extremities are also advanced and longer (Karagoz, 2008). Forehand and backhand are the main techniques in tennis. For this reason, they are used frequently in the game. To perform forehand and backhand stroke, the legs, hips, shoulder muscles and arm muscles must be in harmony (Gul et al., 2017). The racket should be held very tight, and the arm, wrist and grip must be very good during the stroke (Tuzcuoğlu, 2006).

Anthropometry is the systematic measurement technique reflecting the measurements of the human body in quantity (Avar, 2013). It is used for body measurements like body weight, stature, arm length and fat ratio (Sarikaya, 2016). Previous researches showed that some anthropometric changes in tennis players affect the performance of tennis strokes (Aydin et al., 2017). For this reason, anthropometric changes can be considered among the defining criteria for success in sports (Pazarozyurt, 2008). Besides, in previous studies which body structure is suitable for which sport was examined, and it was reported that this situation was effective in determining the suitability of infrastructure in sports (Akturk, 2017).

In this study, the purpose was to examine the effect of some physical characteristics on stroke speed of forehand and backhand techniques in tennis.

\section{Method}

\subsection{The Study Group}

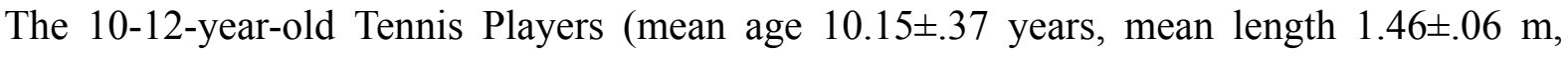
mean body weight $38.77 \pm 6.67 \mathrm{~kg}$, mean sports age $4.76 \pm 1.16$ years) of Isparta Suleyman Demirel University Tennis Courts were participated in the present study. The participants and their parents were informed about the purpose of the study and the possible risks during 
exercise before the test. The athletes participated in the study after all parents approved "Parent Consent Form". Besides, athletes were warned to avoid any drug use or challenging physical activities that might affect body metabolism before the test.

\subsection{Height Measurements}

Height measurements were made with $0.1 \mathrm{~m}$-sensitive metal height scale.

\subsection{Body Weight Measurements}

Body weight measurements were made with $0.5 \mathrm{~kg}$-sensitive electronic scale when athletes wore only short and t-shirt on barefoot.

\subsection{Length Measurements}

For length measurements, $0.1 \mathrm{~cm}$-sensitive non-elastic $7-\mathrm{mm}$ wide measurement tape was used.

\subsection{Circumference Measurements}

For circumference measurements, $0.1 \mathrm{~cm}$-sensitive non-elastic $7-\mathrm{mm}$ wide measurement tape was used.

\subsection{Width Measurements}

The measurements were made at various reference points in the body with doe-foot calipers.

\subsection{Subcutaneous Fat Measurements}

$0.1 \mathrm{~mm} / \mathrm{HG}$-sensitive skinfold caliper was used for this purpose. The measurements were made at dominant side of the body. The measurements were repeated twice and the average of these measurements was recorded.

\subsection{Ball Speed Measurement}

In measuring the speed of the ball, the forehand and backhand strokes were carried out in a closed tennis court to control the effect of the weather. The athletes warmed up until they reached maximal forehand and backhand speed level. Three minutes after the athletes warmed up, testing was started, and the athletes were asked to carry out forehand and backhand strokes at 8 maximal speeds. Sports Radar, Power Madd was used in measuring the speed of the ball. The radar used in measuring the speed of the ball was activated at the moment of the stroke and right after the stroke. The strokes were made in line with the rules of tennis, towards the court, and when the ball stroke the net or when it went outside the baseline (out), these strokes were not recorded. The feedbacks of the strokes were reported to the athletes to spend maximal effort. All strokes were directed towards the parallel point of the court. The coach behind the file sent the balls to the athletes to stroke, and all strokes were evaluated by two tennis coaches (Cohen, 1994).

\subsection{Statistical Analysis}

The "Descriptive Statistics" and "Correlation Analysis" in the statistical package program to 
analyze the data. Significance level was taken as "p $<0.05$ ".

\section{Results}

According to information given in Table 1 the mean age of the athletes was $11.3 \pm 0.6$ (years), mean height was $151.2 \pm 4.0(\mathrm{~cm})$, mean body weight was $40.2 \pm 2.2(\mathrm{~kg})$.

Table 1. Physical characteristics of athletes

\begin{tabular}{|l|l|l|l|l|}
\hline Parameters & N & Mean.SD & Min. & Max. \\
\cline { 1 - 4 } Age (years) & \multirow{3}{*}{10} & $11.3 \pm 0.6$ & 10 & 12 \\
\cline { 1 - 3 } Height $(\mathrm{cm})$ & & $151.2 \pm 4.0$ & 147 & 157 \\
\cline { 1 - 3 } Body Weight $(\mathrm{kg})$ & & $40.2 \pm 2.2$ & 36 & 43 \\
\hline
\end{tabular}

In Table 2, According to $\mathrm{P}$ values there is no significant correlation among parameters between biceps, triceps, chest, scapula, abdomen, iliac and forehand, backhand stroke speeds and subcutaneous fat values $(\mathrm{p}>0.05)$.

Table 2. Relation between subcutaneous fat measurements of the athletes and forehand and backhand strokes

\begin{tabular}{|l|l|l|l|l|l|}
\hline \multirow{2}{*}{ Parameters } & \multirow{2}{*}{ Mean.SD } & \multicolumn{2}{|c|}{ r } & \multicolumn{2}{c|}{ p } \\
\cline { 3 - 6 } & & Forehand & Backhand & Forehand & Backhand \\
\hline Biceps & $8.6 \pm 2.2$ & 125 & 054 & 730 & 883 \\
\hline Triceps & $11.7 \pm 2.0$ & 060 & 114 & 870 & 754 \\
\hline Chest & $9.9 \pm 3.5$ & 090 & 438 & 804 & 206 \\
\hline Scapula & $9.4 \pm 1.8$ & 128 & 108 & 724 & 767 \\
\hline Abdomen & $12.7 \pm 2.7$ & 028 & 306 & 940 & 389 \\
\hline Iliac & $12.6 \pm 2.4$ & 249 & 226 & 488 & 530 \\
\hline
\end{tabular}

Note. ${ }^{*} \mathrm{p}<0.05$.

In Table 3 that no correlation according to $p$ values between knee, elbow, biacromial, chest depth, trochanter and forehand and backhand strokes of athletes $(p>0.05)$. 


\section{Macrothink}

Journal of Educational Issues

ISSN 2377-2263 2020, Vol. 6, No. 1

Table 3. Relation between width measurements of athletes and forehand and backhand strokes

\begin{tabular}{|l|l|l|l|l|l|}
\hline \multirow{2}{*}{ Parameters } & \multirow{2}{*}{ Mean.SD } & \multicolumn{2}{|c|}{ r } & \multicolumn{2}{c|}{ p } \\
\cline { 3 - 6 } & & Forehand & Backhand & Forehand & Backhand \\
\hline Knee & $5.4 \pm 0.5$ & 545 & 230 & 103 & 522 \\
\hline Elbow & $5.4 \pm 0.5$ & 545 & 230 & 103 & 522 \\
\hline Biacromial & $33.6 \pm 2.2$ & 281 & 192 & 432 & 595 \\
\hline Chest depth & $20.2 \pm 6.3$ & 248 & 180 & 490 & 619 \\
\hline Trochanter & $23.5 \pm 2.3$ & 046 & 150 & 899 & 680 \\
\hline
\end{tabular}

Note. $* \mathrm{p}<0.05$.

When Table 4 is examined, it can be seen that there was a positive relation between the hand length and backhand stroke speeds $(\mathrm{p}<0.05)$; and no correlation according to $\mathrm{p}$ values between the arm length, upper arm, forearm, leg, feet lengths and forehand and backhand strokes $(\mathrm{p}>0.05)$.

Table 4. Relation between forehand and backhand strokes and length measurements

\begin{tabular}{|l|l|l|l|l|l|}
\hline \multirow{2}{*}{ Parameters } & \multirow{2}{*}{ Mean.SD } & \multicolumn{2}{|c|}{ r } & \multicolumn{2}{c|}{ p } \\
\cline { 3 - 6 } & & Forehand & Backhand & Forehand & Backhand \\
\hline Arm length & $63.8 \pm 3.7$ & 470 & 345 & 171 & 329 \\
\hline Upper arm & $44.7 \pm 5.0$ & 074 & 057 & 838 & 877 \\
\hline Forearm & $26.9 \pm 6.9$ & 394 & 167 & 259 & 645 \\
\hline Hand & $15.1 \pm 0.5$ & 377 & $\mathbf{6 1 1 *}$ & 283 & $\mathbf{0 3 0 *}$ \\
\hline Leg & $33.9 \pm 3.0$ & 043 & 075 & 906 & 837 \\
\hline Feet & $24.1 \pm 3.0$ & 146 & 467 & 687 & 173 \\
\hline
\end{tabular}

Note. ${ }^{*} \mathrm{p}<0.05$.

It is seen in Table 5 that a positive relation was detected between the head and forehand and backhand stroke speeds $(\mathrm{p}<0.05)$; and no correlation according to $\mathrm{p}$ values between shoulder, chest, waist, abdomen, hip and thigh lengths and forehand and backhand stroke speeds $(\mathrm{p}>$ $0.05)$. 
Table 5. Relation between circumference measurements of athletes and forehand and backhand strokes

\begin{tabular}{|l|l|l|l|l|l|}
\hline \multirow{2}{*}{ Parameters } & \multirow{2}{*}{ Mean.SD } & \multicolumn{2}{|c|}{ r } & \multicolumn{2}{|c|}{ p } \\
\cline { 3 - 6 } & & Forehand & Backhand & Forehand & Backhand \\
\hline Head & $54.3 \pm 3.5$ & 616 & 602 & $\mathbf{0 4 9 *}$ & $\mathbf{0 4 4 *}$ \\
\hline Shoulder & $84.6 \pm 4.9$ & 109 & 192 & 765 & 594 \\
\hline Chest & $74.2 \pm 5.1$ & 231 & 089 & 521 & 807 \\
\hline Waist & $72.3 \pm 5.1$ & 088 & 443 & 809 & 199 \\
\hline Abdomen & $66.9 \pm 4.0$ & 131 & 317 & 718 & 373 \\
\hline Hip & $80.1 \pm 4.9$ & 212 & 284 & 556 & 427 \\
\hline Thigh & $41.6 \pm 3.8$ & 488 & 236 & 194 & 511 \\
\hline
\end{tabular}

Note. ${ }^{*} \mathrm{p}<0.05$.

\section{Discussion}

This study aimed to examine the effect of some physical characteristics of 10-12 aged tennis players on forehand and backhand technique stroke speed in tennis. According to analyze results, it was found that the mean age of male athletes was $11.3 \pm 0.6$ (years), mean length was $151.2 \pm 4.0(\mathrm{~cm})$, mean body weight was $40.2 \pm 2.2(\mathrm{~kg})$. Besides according to the correlation test, no correlation according to $\mathrm{p}$ values between Biceps, Triceps, Chest, Scapula, Abdomen and Iliac, which were among subcutaneous fat measurements $(p>0.05)$. Sogut et al. (2004) conducted a study, and according to their analysis results, the body fat percentages of young male tennis players did not differ at significant levels according to their categories $(p>0.05)$. This study supports our research. According to the results, among the width measurements, a negative relation was detected between the Knee, Elbow, Biacromial, Chest, Trochanter and Forehand and Backhand stroke speeds $(\mathrm{p}>0.05)$. In the study that was conducted by Sogut et al. (2004), according to the results of their analysis, significant differences were detected according to the right hand wrist diameter categories of young male tennis players $(p<0.05)$. According to the results, among length measurements, although a positive relation was detected between hand and especially backhand stroke speed $(\mathrm{p}<0.05)$, a negative relation was detected between Arm Length, Upper Arm, Forearm, Leg and Feet ( $p>0.05)$. Sogut et al. (2004) conducted a study and determined significant differences according to all categories of circumferential measurements of young male tennis players in different categories $(p<0.05)$. They observed significant differences in Left Forearm, Thigh and Calf length measurement categories $(\mathrm{p}<0.05)$. They found significant differences in left humerus, femur and chest diameter measurement categories in young male tennis players $(p<0.05)$. According to the results, a positive relation was detected between the Head, Forehand and Backhand stroke speeds, which are among circumferential measurements $(\mathrm{p}<0.05)$, and a negative relation was 
detected between Shoulder, Chest, Waist, Abdomen, Hip And Thigh ( $p>0.05)$. According to the results of the analysis of the study conducted by Aydin et al. (2017), significant relation were detected between forehand strokes and height, weight, full shoulder, biceps circumference, elbow circumference, and hand length $(\mathrm{p}<0.05)$. They could not find any relations between backhand stroke scores and other variables $(\mathrm{p}>0.05)$. Diker et al. (2017) reported that in order to perform the best forehand and backhand strokes, the following were necessary; accurate perception of the speed of the coming ball, the speed of the racket at the time of hitting the ball, tight grip of the racket during the hit of the ball, strong grip of the wrist and arm, accurate timing of the ball hitting the racket, and the angle of the racket during the stroke must be good. In tennis, athletes need a high level of physical proficiency during the game. Tennis is an individual sport, and it is important that physical fitness levels like fast direction changes, quick and strong arm movements and jumps are at the highest level during the game. Other factors that affect success in tennis are adequacy of technical levels, game intelligence, and mental state levels. The physical and physiological characteristics of the individual are important when athletes are selected. The characteristics a tennis player should have are being high, long arms, high anaerobic power, and aerobic capacity, coordination, durability, and tactical intelligence.

As a result, sports scientists and coaches must pay attention to technical development levels of athletes as well as their physical characteristics in the preparation of a training program for 10-12 year old male tennis players. It can be considered that strength development can be achieved with an accurate technique, and depending on this, the speed of the ball will increase. Since physical development is mostly at directly proportional to age, it is considered that ball speed will be affected as the age increases.

\section{References}

Aktürk, S. (2017). 17-25 Yaş Grubu Gençlerde Düzenli Tenis Çalışmalarının Bazı Fiziksel ve Motorik Özelliklere Etkisinin Araştırılması (Yüksek Lisans Tezi Atatürk Üniversitesi Sağlık Bilimleri Enstitüsü. Erzurum).

Cohen, D. B., Mont, M. A., Campbell, K. R., Vogelstein, B. N., \& Loewy, J. W. (1994). Upper extremity physicalfaktorsaffecting tenis serve velocity. The American Journal of Sports Medicine, 22(6), 746-750. https://doi.org/10.1177/036354659402200604

Diker, G., Zileli, R., Özkamçı, H., \& Ön, S. (2017). Genç Tenis Oyuncularının Bazı Fizyolojik ve Biyomotor Özelliklerinin Değerlendirilmesi. Uls Spor Egzersiz \& Antrenman Bilimi Dergisi, 3(1), 25-32. https://doi.org/10.18826/useeabd.296396

Gül, G. K., Konyalı, M., \& Gül, M. (2017). Pliometrik Antrenmanların Tenis Servis İsabetine Etkisi. Beden Eğitimi ve Spor Araştırmaları Dergisi, 1(9), 68-73.

Pazarözyurt, İ., \& İnce, G. (2009). Elit Bayan Basketbolcularda Antropometrik Özellikler, Dikey Sıçrama ve Omurga Esnekliğinin Mevkilere Göre İncelenmesi. Spormetre Beden Eğitimi ve Spor Bilimleri Dergisi, 7(1), 9-18. https://doi.org/10.1501/Sporm_0000000144 


\section{Macrothink

Pektaş, N. A. (2016). Tenisçilerde Teknik Parametrelerin Modellenen Müsabaka Süresince Analizi (Yüksek Lisans Tezi, Selçuk Üniversitesi, Sağlık Bilimleri Enstitüsü Konya).

Sarıkaya, M. (2016). Üniversite Takımlarında Oynayan Badminton Ve Tenisçilerin Bazı Fiziksel ve Fizyolojik Parametrelerin Karşılaştırılması (Yüksek Lisans Tezi, Gaziantep Üniversitesi Sağlık Bilimleri Enstitüsü, Gaziantep). https://doi.org/10.16992/ASOS.982

Söğüt, M., Müniroğlu, R. S., \& Deliceoğlu, G. (2004). Farklı Kategorilerdeki Genç Erkek Tenis Oyncularının Antropometrik ve Somatotip Özelliklerinin İncelenmesi. Spormetre Beden Eğitimi ve Spor Bilimleri Dergisi, 11(4), 155-162. https://doi.org/10.1501/Sporm_ 0000000040

Tuzcuoğlu, S. (2006). Taktik Oyun Yaklaşımının Tenis Öğretimi Üzerine Etkisi (Yüksek Lisans Tezi, Abant İzzet Baysal Üniversitesi Sosyal Bilimler Enstitüsü, Bolu). https://doi.org/ 10.1501/Sporm_0000000040

Karagöz, Ş. (2008). 8-10 Yaş Arası Çocuklarda 12 Haftalık Tenis Antrenmanlarının Görsel ve İşitsel Reaksiyon Zamanina Etkisinin İncelenmesi (Yüksek Lisans Tezi. Afyon Kocatepe Üniversitesi Sağlık Bilimleri Enstitüsü Afyonkarahisar).

Avar, P., \& Akça, F. (2013). 10-12 Yaş Grubu Tenisçilerin Türkiye Klasman Sıralamalarına Göre Antropometrik Özellikleri ve Servis Hızlarının İncelenmesi. Spormetre Beden Ĕ̆itimi ve Spor Bilimleri Dergisi, 11(1), 35-40. https://doi.org/10.1501/Sporm_0000000236

Aydın, R., Çiftçioğlu, A., Altınel, S., \& Özkan, A. (2017). 10-12 Yaş Grubu Tenisçilerin Bazı Kinantropometrik Değişkenlerinin ve Forehand-Backhand Vuruş Tekniklerinin İncelenmesi. Uluslararası Kültürel ve Sosyal Araştırmalar Dergisi, 3(2), 319-325.

\section{Copyright Disclaimer}

Copyright for this article is retained by the author(s), with first publication rights granted to the journal.

This is an open-access article distributed under the terms and conditions of the Creative Commons Attribution license (http://creativecommons.org/licenses/by/3.0/). 